\title{
DIE KONSEP BELY/BELYDENIS IN DIE NUWE TESTAMENT 1
}

'n Bepaling van dic belangrikste Griekse woorde en voorlopige definiêring van betckenisse

Fika J. van Rensburg

Departement Grieks

Teologiese Skool Potchefstroom en PU vir CHO

POTCHEFSTROOM

\begin{abstract}
THE CONCEPT PROFESS/PROFESSION IN THE NEW TESTAMENT

Determination of important Greck words and preliminary definition of mcanings

The aim of this article is to detcrmine the most important Greek words for the concept profess/profession in the Ncw Testament, and to give preliminary definitions of applicable meanings for these words. The scmantic model within which this study is underaken, is the symchronic stncturalist view of meaning, and the dota in the Louw-Nido Dictionary are utilized. Ass staring point a dcfinition of the concept profess/profession is given. The words in the Greek New Testament are detennined by cxamining acknowledged professions in the New Testament, as well as encouragements and possible allusions to profess The meanings within the different subdomains are contrasted in different ways. In conclusion the Greek words for the concept profess/profession are listed, and a defmition of each meaning is given.
\end{abstract}

\section{INLEIDING}

\subsection{Afbakening}

Die oogmerk met hierdie artikel is nie om 'n omvattende studie van die konsep bely/ belydenis te onderneem nie, maar om die belangrikste woorde in die Nuwe Testament wat relevant vir die omvattende teologiese bestudering van die konsep bely/belydenis is, aan te merk en die tersaaklike betekenisse daarvan voorlopig te definieer.

${ }^{1}$ Hicrdic arlikel vorm deel van die recks artikels oor die belydenis en die belydenisskrifte. Kyk ook In die Skriflig 25(1)1991. Ook is hierdie artikel die ecrste in 'n reeks van drie deur lede van dic Departement Nuwc-Testamenticse Vakkc onder die brečr tema Die bely(denis)-motief in die Nuwe Testament. Dic ander Iwec artikels is die volgende: "Die begrip bely/belydenis in die Evangelies en Handelinge: 'n openbaringshistoriese studie" (G.J.C. Jordaan), en "n Eksegeticse 


\subsection{Semantiese model}

Die semantiese model waarbinne hierdie studie gedoen word, is die sinkroniesstrukturalistiese siening van die aard van betekenis, soos onder andere vergestalt in die die Louw \& Nida-woordeboek (Louw \& Nida, 1988).

\subsection{Opset}

Eerstens word die woorde wat in die Griekse Nuwe Testament vir die konsep bely/ belydenis gebruik word, bepaal (2). Daarna word die betrokke betekenisse binne die betrokke semantiese domeine op verskillende wyses gekontrasteer (3). In 'n samevattende gevolgtrekking word 'n lys van die Griekse woorde saamgestel en die betekenisse voorlopig gedefinieer (4).

\section{GRIEKSE WOORDE VIR DIE KONSEP BELY/BELYDENIS}

Die vasstelling van die Griekse woorde wat in die semantiese veld bely/belydenis gebruik word, word langs twee weë onderneem: eerstens word Skrifdele wat tradisioneel beskou word as (kern-)belydenisse, asook die inleidingsformules van daardie belydenisse, aan die orde gestel (2.1); daarna word Skrifdele waarin daar moontlike verwysings na of opdragte in verband met bely/bclydenis voorkom, behandel (2.2).

\section{1 (Kern-)belydenisse in die Nuwe Testament}

Gedeeltes in die Nuwe Testament waarvan daar redelike algemene erkenning is dat dit (kernagtige) belydenisse is, is die volgende (vgl. Schaff, 1877:4-7): die belydenis deur Natanael in Johannes 1:49, die belydenis deur Petrus in Matteus 16:16 en Johannes 6:68-69, die belydenis deur Tomas in Johannes 20:28, die doopformule in Matteus 28:19, die belydenis van die eenheid van God die Vader en Christus in 1 Korintiërs 8:6, die belydenis oor die geopenbaarde waarheid van die godsdiens in 1 Timoteus 3:16, en die sogenaamde elementêre artikels in Hebreërs 6:1-2.3

Handelinge: 'n openbaringshistoriese studie" (G.J.C. Jordaan), en "'n Eksegeticse studie van fasetle van bely/betydenis in die Hebreềrpreek" (J. Christi Coctzee).

${ }^{2}$ Die verskille wat daar in dic parallelle in Markus 8:29 en Lukas 9:20 voorkom, is vir dic ongmerk van dic huidige behandeling nie van belang nie. Daarom word hierdie twee gedecltes nie sclfstandig aan die orde gestcl nie.

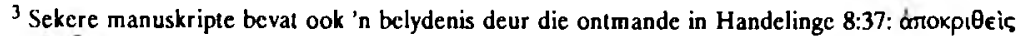

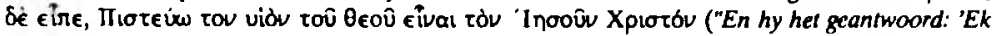


Slegs 1 Timoteus 3:16 is vir die doeleindes van hierdie artikel ter sake. In drie gevalle (Mat. 28:19, 1 Kor. 8:6 en Heb. 6:1-2) word nòg in die belydenis self, nòg in die argument waarin dit geïntegreer is, enige woorde wat na die bely-handeling verwys, gebruik. Die werkwoorde wat in die ander tekste gebruik word om telkens die belydenis in te lei, naamlik droxpivoual (Joh. 1:49, Mat. 16:16, Joh. 6:49, Joh. 20:28)

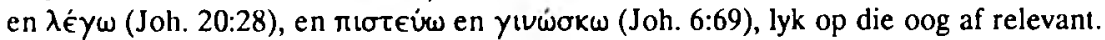
'n Bestudering van bogenoemde tekste laat egter blyk dat hierdie werkwoorde nie primêr op die konsep bely/belydenis betrekking het nie.

Die rede waarom 1 Timoteus 3:16 betekenisvol is, is die gebruik van die woord

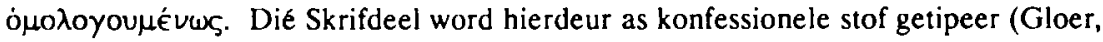
1984:124). Neufeld (1963:13-33) verklaar selfs dat die woordgroep ó ò woonlik na 'n spesifieke konfessionele tradisie. Daar is dus voldoende grond om af te

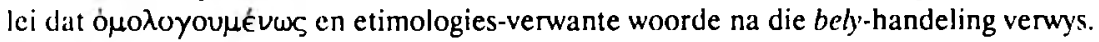

Ten opsigte van die (kern)belydenisse in die Nuwe Testament is die gevolgtrekking dus

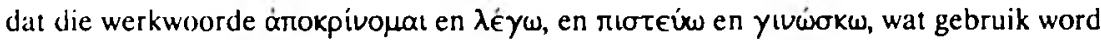
om 'n belydenis in te lei, nie primêr op die konsep bely/belydenis betrekking nie. Hierdie werkwoorde is dus vir die doeleindes van die artikel nie primêr ter sake nie. Dic woord ópoגnyoupévws (en moontlik etimologies-verwante woorde) blyk egter wel primèr ter sake te wees.

\subsection{Skrifdele waarin daar aanmoediging tot of moontlike verwysings na belydenis voorkom}

Daar is ook gedeeltes in die Nuwe Testament wat, alhoewel daar nie ' $n$ belydenis self daarin voorkom nie, aansporings tot of moontlike verwysings na bely/belydenis bevat. Hlierdie twee kategorieë kom agtereenvolgens aan die orde.

\subsubsection{Aanmoediging tot belydenis}

In Matteus 10:32-334 moedig Jesus mense aan om Hom te bely:

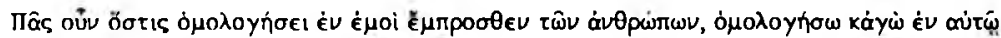

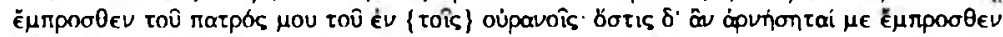

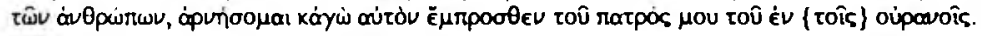

glo dar U die Seltn van God, Jesus Christus is'"). Die gebruikte grondteks (UBS ${ }^{3}$ ) bevat egter nie die vers nie. Dit beval in elk geval nie nuwe tersaaklike inligting nie.

${ }^{4}$ Die verskille in die parallelle gedeelte in Lukas 12:8-9 het geen implikasie vir die huidige ondersoek nic. Daarom word hierdie gedeelte nie selfstandig aan die orde gestel nie. 
"Elkeen wat hom voor die mense openlik vir My uitspreek, vir hom sal Ek My openlik uitspreck voor my Vader wat in dic hemel is. Maar hom wat My voor die mense verloen, sal Ek ook verloen voor my Vader wat in die hemel is."

In Romeine 10:9-10 kom dieselfde tipe aanmoediging uit die pen van Paulus:

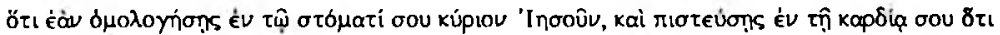

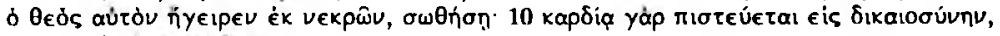

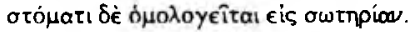

"As jy met jou mond bely dat Jesus die Here is, en met jou hart glo dat God Hom uit die dood opgewek het, sal jy gered word. Met die hart glo ons, en ons word vngespreek; en met die inond bely ans, en ons word gered."

In albei hierdie Skrifdele is dit duidelik dat ó $\mu \circ \lambda \circ \gamma \in$ éw op die bely-handeling betrekking het.

\subsubsection{Moontlike verwysings na belydenis}

Moontlike verwysings na belydenis kom voor in Romeine 12:6, 1 Korintiërs 15:3, 1 Johannes $4: 2-3,2$ Johannes 9-10, en Judas 3. Hierdie gedeeltes word nou agtereenvolgens aan die orde gestel.

In Romeine 12:6 moedig Paulus gelowiges wat die gawe van profesie ontvang het, aan

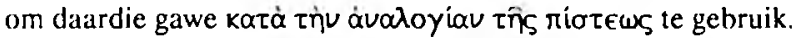

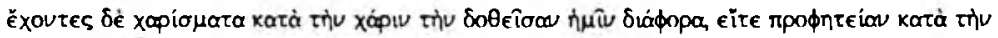

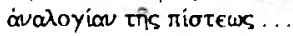

"Ons het genadegawes wat van mekaar verskil volgens die genade wat God aan elkeen van ons gegee het. As dit die gawe is om God se boodskap le verkondig, laat ons dit gebruik in ooreenstemming met die geloof wat ons bely."

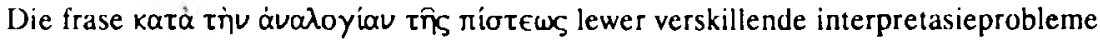

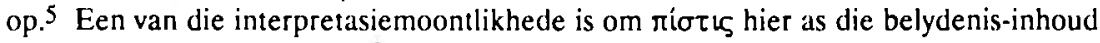
van die geloof op te neem; 6 dit is skynbaar ook die weg wat die 1983 -Afrikaanse vertaling gevolg het.

5 Vergelyk onder andere Louw \& Nida (1988,1:778) se inskrywing 89.10 in verband met óvaloyia, en Hendriksen (1981:410) se behandeling van dic frase.

${ }^{6}$ Hierdie betckenismoontlikheid van rior 15 word in die Louw-Nida-woordebock (Louw \& Nida 1988,1:379) onder inskrywing 31.104 (riatis': doctrine) aan die orde gestel. Judas 3 en Galasiërs 1:23 word as moontlike voorbeelde genoem. Die betekenisdefinisic is: the content of what Christians believe (Louw \& Nida 1988,I:379). 


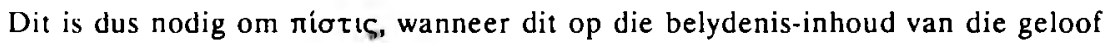
betrekking het, in berekening te bring by die bestudering van die bely/belydenis-motief in die Nuwe Testament.

In 1 Korintiërs 15 is Paulus besig om die gelowiges te herinner aan die evangelie wat hy verkondig het. In vers 2 spoor hy hulle aan om vas te hou aan die boodskap soos hy dit aan hulle verkondig het. In verse $3 b-8$ vermeld hy die hoofsaak van hierdie boodskap. Die inleidingswoorde in vers $3 \mathrm{a}$ is van belang:

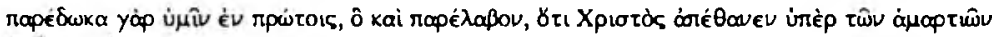

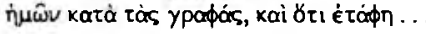

"Die belangrikste wat ck aan julle oorgelewer het en wat ek ook ontvang het, is dit: Christus het vir ons sondes gesterf, volgens die Skrifte; Hy is begrawe ..."

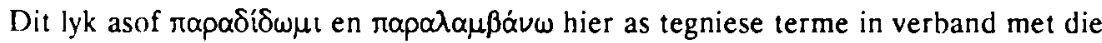
ontvangs en oorlewering van belydenisinhoud gebruik word. Hierdie woorde moet dus, veral wanneer dit belydenisinhoud as voorwerp het, in berekening gebring word by die bestudering van die konsep bely/helydenis.

In 1 Johannes 4:2-3 skryf die outeur baie spesifiek oor die belydenis van Jesus as die Christus:

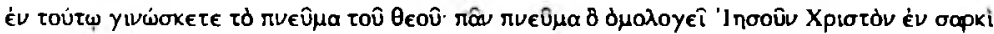

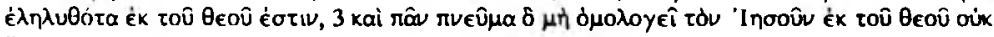
ย̆otw

"Hieraan ken julle die Gees van God: elkeen wat bely dat Jesus werklik dic Christus is wat mens geword het, het die Gees wat van God afkomstig is. En elkeen wat dit nie van Jesus bely nie, her nic die Ciees wat van God afkomstig is nie."

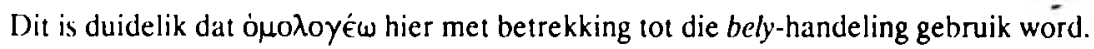

In 2 Johannes 9-10 word gehandel oor die "leer oor Christus":

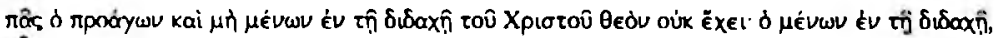

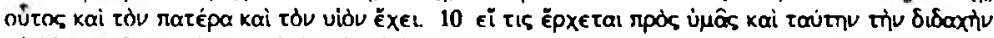

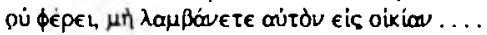

"Elkeen wal 'n contreder is en nie by die leer oor Chrisfus bly nie, erken God nie. Wie in die leer bly, erken sowel die Vader as die Seun. As daar iemand na julle toe kom wat 'n ander leer bring. moet julle hom nie in julle huise ontvang nie..." (Eie vertaling) 


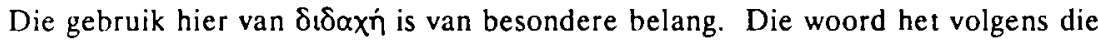
Louw-Nida-woordeboek twee betekenismoontlikhede in die Nuwe Testament, naamlik a) onderrig 7 , en b) leerstelling ${ }^{8} . \Delta \downarrow \delta \alpha \times \eta^{b}$ het betrekking op die belydenisinhoud, te meer wanneer dit een konstruksie met Xptotós as objektiewe genitief vorm. Hierdie gebruik van $\delta\llcorner\delta \alpha \times n$ moet in berekening gebring word by die bestudering van die bely/belydenis-motief in die Nuwe Testament.

In $\underline{\text { Judas } 3}$ word melding gemaak van die "oorgelewerde geloof":

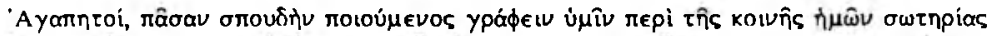

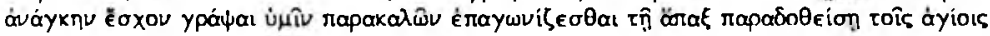
ríazel.

"Geliefdes, ek was van plan om aan julle te sknwwe oor die vertossing waaraan ons almal deel het. Maar nou voel ek verplig om julle met my brief aan te spoor om te stry vir dic geloof wat een maal oorgelewer is aan die wat God vir Hom afgesonder het."
\end{abstract}

Tiot is dui hier, soos by Romeine 12:6, op die belydenisinhoud van die geloof. Verder word hier weer, soos by 1 Korintiërs 15:3, 'n vorm van die werkwoord rapa $\delta i \delta \omega \mu t$ in verband met die ontvangs en oorlewering van belydenisinhoud gebruik.

Op grond van hierdie kort bestudering van Skrifgedeeltes wat aansporings tot of moontlike verwysings na bely/belydenis bevat, is dit duidelik dat die volgende woorde/uitdrukkings in berekening gebring moet word by die bestudering van die

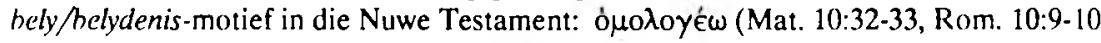

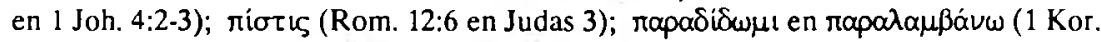

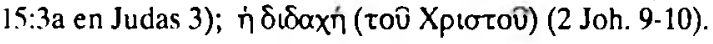

\title{
2.3 Gevolgtrekking
}

\subsubsection{Woorde van sekondère belang}

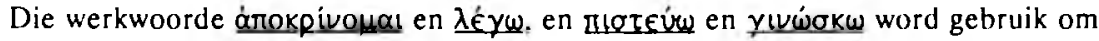
belydenisse in te lei. Omdat hierdie vier werkwoorde nie direk op die konsep bely/helydenis betrekking het nie, is dit nie van nut om die betekenisdefiniering van die tersaaklike gebruike van die vier werkwoorde te onderneem nie, en word dit ook nie in hierdie studie gedoen nie. In die bestudering van die bely/belydenis-motief in die

\footnotetext{
${ }^{7}$ Vergelyk Louw \& Nida (1988,1:413-414) se inskrywing 33.224.

${ }^{8}$ Vergelyk Louw \& Nida (1988,I:415) se inskrywing 33.236; die betekenisdefinisie is: the content of what is taught.
} 
Nuwe Testament, sal dit egter wel nodig wees om die voorwerpsinne by hierdie werkwoorde, of die direkte rede wat daarop volg, te ondersoek met die oog daarop om vas te stel of daardie voorwerpsin of direkte rede nie 'n belydenis is of belydenisinhoude bevat nie.

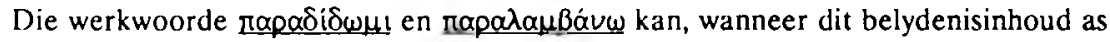
voorwerp het, as tegniese terme in verband met die ontvangs en oorlewering van die belydenisinhoud van geloof gebruik word (vgl. Delling 1967:13). In die bestudering van die bely/belydenis-motief in die Nuwe Testament, sal dit egter wel nodig wees om telkens die voorwerp(-sin) by hierdie werkwoorde te ondersoek met die oog daarop om vas te stel of daardie voorwerp(-sin) 'n belydenis is of belydenisinhoude bevat. Vanweë die feit dat die werkwoorde slegs indirek op die konsep bely/belydenis betrekking het, is dit nie nuttig om die definiëring van die tersaaklike betekenisse van die twee werkwoorde te onderneem nie.

II írıs 9 het ses betekenismoontlikhede, naamlik (Louw \& Nida 1988,II:198):10 a) what can be believed (31.43) [bewys]; b) trust (31.85) [geloof]; c) trustworthiness (31.88) [trou/betroubaarheid]; d) Christian faith (31.102) [Christelike geloof]; e) doctrine (31.104) [leerstelling]; f) promise (33.289) [trou-belofte]. Vir die

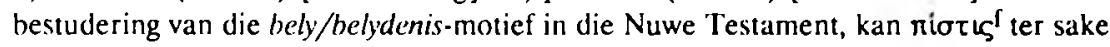
wecs. Dic betekenisdefinisie daarvan is: a promise or pledge of faithfulness and lovaly (Louw \& Nida 1988,1:421). Dit beteken dat dit nodig sal wees om die gebruik van

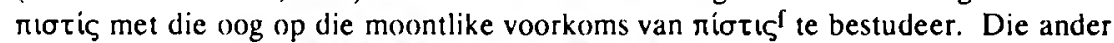
betekenisse, naamlik $\pi \iota \sigma \tau \zeta^{\mathrm{a}-\mathrm{c}}$, en veral $\pi \tau^{\circ} \mathrm{i}^{\mathrm{c}}$, wat in Domein 31 (Hold a view, believe, trust [standpunt huldig, glo, vertrou]) figureer, is wel van indirekte belang.

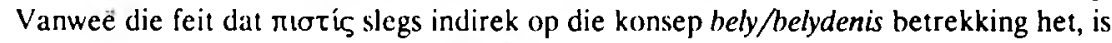
dit nie van nut om die betekenisdefiniëring van die tersaaklike betekenisse daarvan te onderneem nie.

$\Lambda 1 \delta \alpha \times n$ het twee betekenismoontlikhede, naamlik (Louw \& Nida 1988,11:62): a) teaching (33.224) [onderrig]; b) doctrine (33.236) [leerstelling]. Die etimologies

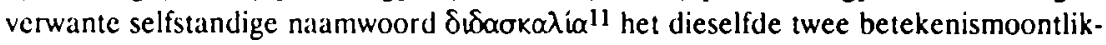

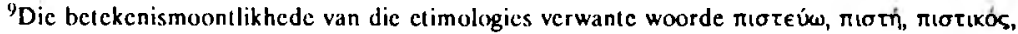

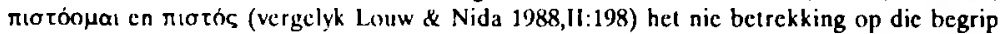
bely/belydenis soos in punt 2 gedefiniccr nic. Dit is daarom nic nodig om verder daaraan aandag te gee nic.

${ }^{10}$ Die nommers tussen hakies verwys telkens na die inskrywing in die Louw-Nida-woordeboek. Tussen vierkantige hakies is 'n Afrikaanse ckwivalent van dic hetrokke betekenismoontlikheid.

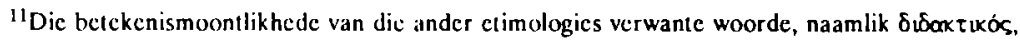


hede as $\delta$ $\delta \alpha \times \dot{\eta}$ (Louw \& Nida 1988,II:62). Vir die bestudering van die bely/belydenismotief in die Nuwe Testament, is $\delta 1 \delta \alpha \times \eta^{a}$ nie ter sake nie; $\delta 1 \delta \alpha \times \eta^{b}$, wat in Domein 33

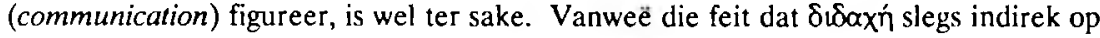
die konsep bely/belydenis betrekking het, is dit nie nuttig om die betekenisse daarvan te definieer nie.

\subsubsection{Woorde van meer primêre belang}

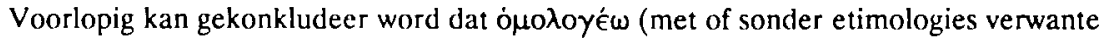
woorde, en waarskynlik met insluiting van woorde met kontrasterende betekenis) in 'n meerdere of mindere mate in sekere opsigte direkte betrekking op die konsep bely/belydenis het, en dus van primêre belang is.

\section{KONTRASTERING VAN BETEKENISSE BINNE DIE TERSAAKLIKE SUBDOMEINE}

Die definiëring van die tersaaklike betekenisse van hierdie woord(-e) is dus vir die oogmerk van hierdie artikel belangrik. Dit kan egter eers suksesvol onderneem word nadat die beginsel van kontrastering van betekenisse toegepas is.

Die kontrastering van die betekenisverskille tussen verskillende woorde binne dieselfde semantiese veld is 'n effektiewe tegniek om by ' $n$ noukeurige definisie van ' $n$ woordbetekenis uit te kom (Botha 1989a en 1989b; Louw \& Nida 1988,I:xi). Die gegewens van die Louw-Nida-woordeboek (Louw \& Nida 1988) word vir hierdie doel ontgin.

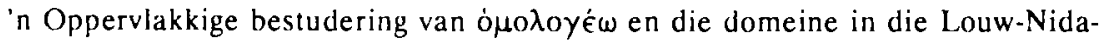
woordeboek, laat blyk dat (veral?) Domein 33 ter sake is. Eerstens word hierdie voorlopige konklusie in verband met Domein 33 geverifieer en bepaal watter subdomeine van Domein 33 ter sake is (4.1). Vervolgens word die betekenisse binne die Subdomeine R.V gekontrasteer (4.2), en laastens word die betekenisse binne Subdomeine $U$ en $V$ gekontrasteer (4.3).

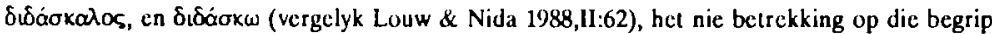
bely/belydenis soos in punt 2 gedefiniecr nie. Dit is daarom nie nodig om verder aan hierdie woorde aandag le gee nie. 


\subsection{Die tersaaklike domeine en subdomeine}

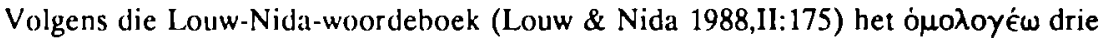
betekenismoontlikhede, naamlik: a) profess (33.274) [uitspreek vir]; b) admit (33.275)

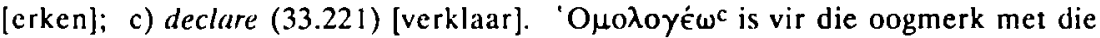
huidige studie nie ter sake nie, aangesien dit in hierdie betekenis bloot oor 'n

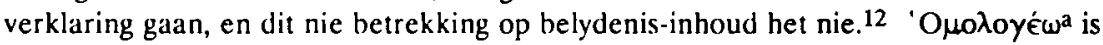
wel ter sake. Die betekenisdefinisie is to express openly one's allegiance to a proposition or person (Louw \& Nida 1988,1:419). Net so is ómoגoyé $\omega^{\mathrm{b}}$ ook ter sake. Die betekenisdefinisie van ó $\mu \circ \lambda \circ \gamma \in \omega^{\mathrm{b}}$ is: to acknowledge a fact publicly, often in reference to previous bad behaviour (Louw \& Nida 1988,1:420).

Die etimologies verwante selfstandige naamwoord ó $\mu$ oגoyí het net een betekenismoontlikheid, naamlik profession (33.274) [belydenis] (Louw \& Nida 1988,II:175; vgl.

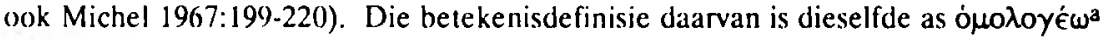
s'n.

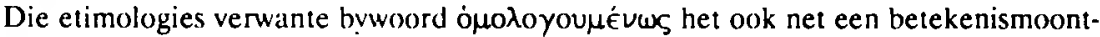
likheid: must be admitted (33.276) [onteenseglik] (Louw \& Nida 1988,II:175). Hierdie

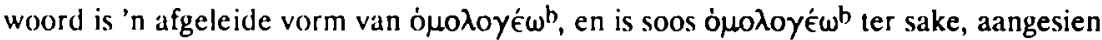
dit met betrckking tot belydenisinhoude, soos hierbo in 2.1 aangetoon is, die aard van

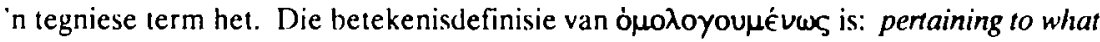
must or should be admitted or acknowledged publicly (Louw \& Nida 1988,I:420).

Binne Domein 33 is dus slegs Betekenis 33.274 en Betekenisse 33.275-33.277 ter sake. Die Griekse woorde wat vir hierdie betekenisse gebruik word, is ó $\mu \circ \lambda o \gamma \in \omega^{a+b}$,

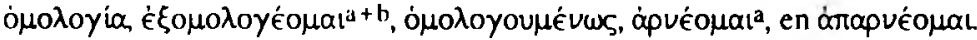

Louw \& Nida (1988,1:388-444) behandel 489 betekenisse in Domein 33. Hierdie 489 betekenisse is onderverdeel in 56 subdomeine (Louw \& Nida 1988,1:388-389). Hierbo (4.1) is gekonkludeer dat betekenisse 274 en $275-277$ vir die huidige ondersoek ter sake is. Ilierdie betekenisse val onderskeidelik in Subdomein U: profess allegiance (33.274) [openlik uitspreek vir], en Subdomein V: admit, confess, deny (33.275-33.277) [erken, bely, ontken]. Subdomeine $U$ en $V$ vorm 'n onderdeel van 'n groep subdomeine wat 'n bepaalde gemeenskaplikheid vertoon, naamlik Subdomeine R-V:

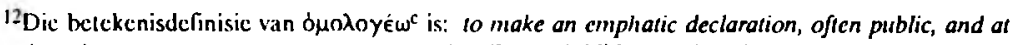
times in response to pressure or an accusation (Louw \& Nida 1988,1:413).
} 
R Speak truth, speak falsehood (33.251-33.255) [waarheid/valsheid praat]

S Preach, proclaim (33.256-33.261) [predik, verkondig]

T Witness, testify (33.262-33.273) [getuig, bevestig]

U Profess allegiance (33.274) [openlik uitspreek vir]

$\mathrm{V}$ Admit, confess, deny (33.275-33.277) [erken, bely, ontken]

Die groepering Subdomeine R-V word deur Louw \& Nida (1988,I:388) getipeer as domeine wat geïmpliseerde waarheid en die relasie van die spreker tot daardie waarheid as belangrike faktor het. Dit is derhalwe belangrik om met die oog op die kontrastering, Subdomeine R, S, T, U, en V saam as groep te oorsien.

\subsection{Kontrastering van betekenisse binne die Subdomeine R-V}

Die oogmerk met hierdie kontrastering is om die betekenisse van die Griekse woorde

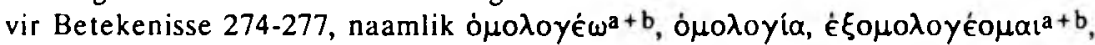

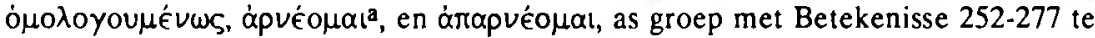
kontrasteer om sodoende fasette van die uniekhede van hierdie betekenisse te bepaal.

Die vernaamste diagnostiese komponente van Betekenisse 251-277, bepaal op grond van die betekenisdefinisies in die Louw-Nida-woordeboek, word derhalwe in die onderstaande matriks met mekaar gekontrasteer. Die tersaaklike betekenisse word langs mekaar aan die regterkant van die matriks met behulp van die betekenisnommers gegroepeer (ter wille van die ruimte word die "33." telkens uitgelaat), en die diagnostiese komponente onder mekaar aan die linkerkant. Die aanwesigheid van die betrokke komponent word met ' $n$ " + " gemerk, en die afwesigheid met 'n "-"; wanneer die betrokke komponent opsioneel is, word dit met ' $n$ ".$+ "$ gemerk. Vanweë die talle betekenisse word die matriks in twee verdeel. Ter wille van effektiewer kontrastering word Betekenis 274 ook in die eerste matriks vermeld: 
Komponentc

Betekenisse

$\begin{array}{llllllllllllll}274 & 251 & 252 & 253 & 254 & 255 & 256 & 257 & 258 & 259 & 260 & 261 & 262 & 263\end{array}$

1. Kummunikasie

Aard van kommmunikasie

2. Privaal

3. Openlik

$\begin{array}{llllllllllllll}+- & + & + & +- & + & + & - & - & - & - & - & - & + & + \\ + & +- & + & + & + & + & + & + & + & + & + & + & + & +\end{array}$

Oognerk met kommunikasie

4. Eic trou-vermelding

5. Oorreding

6. Bedrog

7. Bctuig persoon/saak

8. Betuig ncgatief

Inhoud van kommunikasie

9. Evangelic, leerstellings

10 Vermeld eic getrouheid

11 Hoop

12 Waarheid

13 Eerstehandse kennis

14 Erkenning/ontkenning

\begin{tabular}{|c|c|c|c|c|c|c|c|c|c|c|c|c|}
\hline - & + & +- & + & + & +- & + & + & + & + & $=$ & + & $+\cdot$ \\
\hline+ & - & - & - & - & - & - & - & - & - & - & - & - \\
\hline+- & $\dot{+}-$ & $\div$ & - & - & - & $\div$ & +- & $\leftarrow$ & + & + & 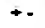 & - \\
\hline+ & + & + & - & - & $=$ & + & + & + & + & + & + & + \\
\hline$+=$ & $+=$ & + & $4-$ & +- & $\rightarrow-$ & $\div-$ & +- & +- & + & +- & - & + \\
\hline - & - & - & - & - & - & - & - & - & - & - & - & - \\
\hline
\end{tabular}

Betekenisse

Komponentc

$\begin{array}{llllllllllllll}274 & 264 & 265 & 266 & 267 & 268 & 269 & 270 & 271 & 272 & 273 & 275 & 276 & 27\end{array}$

1. Kommunikasic

$+++++++++++++$

Aard van kommunikasie

2. Privaat

3. Openlik

Oognnerk met kommunikasie

4. Eic Irou-vermelding

5. Oorreding

6. Bedrog

7. Beluig persoon/saak

8. Betuig negatief

Inhoud van kommunikasie

9 Evangclie, lccrstcllings

10 Vermeld cie getrouheid

11 Hoop

12 Waarhcid

13 Ecrstchandsc kcnnis

14 Erkenning/ontkenning 
Dic bostaande matrikse spreek grootliks vir sigself. Dit is egter verhelderend om die aandag op enkele aangeleenthede te vestig.

Die komponente wat by alle betekenisse gemeenskaplik is, is Komponente 1 (kommunikasie) en 3 (openlike aard van kommunikasie). 'n Komponent wat grootliks gemeenskaplik is, is 11 (hoop).

Die besonderse eienskappe van Betekenisse 274-277 word des te duideliker, wanneer opgemerk word dat die volgende komponente, wat grootliks by Betekenisse 251-273 aanwesig is, by hulle afwesig is: Komponent 5: oorreding as oogmerk met die kommunikasie; Komponent 6: bedrog as oogmerk met die kommunikasie; Komponent 7: betuiging van 'n persoon/saak as oogmerk met kommunikasie; Komponent 8: negatiewe betuiging as oogmerk met die kommunikasie. Ook is dit insiggewend om die teenoorgestelde aan te merk, naamlik dié komponente wat by een of meer van Betekenisse 274-277 aanwesig is, maar by Betekenisse 251-273 afwesig is: Komponent 4: vermelding van eie trou as oogmerk met die kommunikasie; Komponent 10: vermelding van eie trou as inhoud van die kommunikasie.

Hierdie uniekhede van Betekenisse 274-277 (en dus van die Griekse woorde

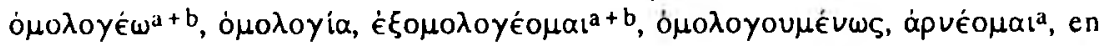
árapvéoral) sal by die bestudering van die bely/belydenis-motief in die Nuwe Testament verdiskonteer moet word.

\subsection{Kontrastering van betekenisse binne Subdomeine U en V}

Die oogmerk met hierdie kontrastering is om die betekenis van die Griekse woorde vir

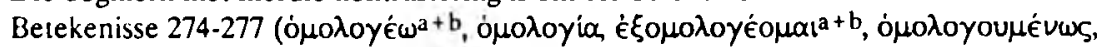

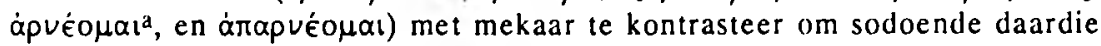
betekenisse akkuraat te definieer.

Dieselfde diagnostiese komponente as in die matrikse hierbo word gebruik, en in die matriks self word ook op dieselfde wyse van simbole gebruik gemaak. Regs van die matriks word die matriks in punte (a) tot (g) toegelig. Ten slotte word die inligting in die matriks geïnterpreteer om vas te stel watter lig dit op die betekenisse van

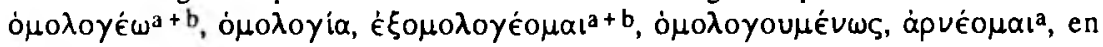

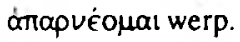


Betekenissc

$274 \quad 275 \quad 276 \quad 277$

Komponcnic

1. Kommunikasic ++++

Aard van kommunikasie

2. Privaat

3. Openlik

Oognerk met konmunikasie

4. Eic trou-vermelding

5. Oorreding

6. Bedrog

7. Betuig persoon/saak

8. Betuig negatief

Inhoud van komunumikasie

9 Evangelic, lccrstcllings

10 Vermeld cic getrouheid

11 Hoop

12 Waarheid

13 Eerslehandsc kennis

14 Erkenning/ontkcnning

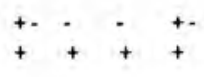

b Komponent 2 is afwesig by Belekenisse 275 en 276, terwyl dit by Betekenis 274 en 277 opsioncel is.

c Komponent 4 is net by Bctckenis 274 tecnwoordig.

d Komponent 9 is by Betekenis 274 afwesig, terwyl dit by 275-277 opsioneel is.

c Komponent 10 is net by Betckenis 274 teenwoordig.

f Komponent 12 is by Bctekenisse $275-276$ teenwoor dig, terwyl dit by 274 en 277 opsioneel is.

g Komponent 14 is by Betckenis 274 afwesig, en by $275-277$ teenwoordig.

Op grond van elk van die toeligtingspunte kan die volgende gevolgtrekkings gemaak word:

Tocliptinga: Ten opsigte van die volgende komponente moet daar in die interpretasie

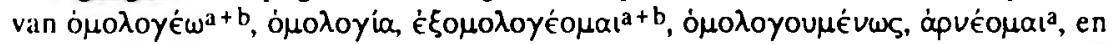

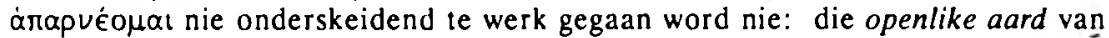
kommunikasie; die afwesigheid van oorreding as oogmerk met die kommunikasie; die afwesigheid van bedrog as oogmerk met die kommunikasie; die afwesigheid van enige betuiging van 'n persoon of saak; die moontlike aanwesigheid van hoop as inhoud van die kommunikasie; die moontlike aanwesigheid van eerstehandse kennis as inhoud van die kommunikasie.

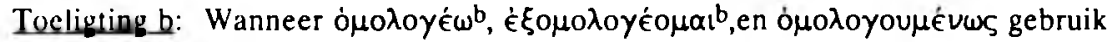
word, is die aard van die kommunikasie noodwendig openbaar en nie privaat nie. In die

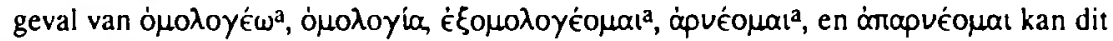
egter ook privaat wees.

Toeligtings: Die vermelding van eie trou as oogmerk met die kommunikasie is net en

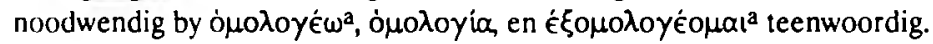


Toeligting d: Die Evangelie of leerstellings as inhoud van kommunikasie is by

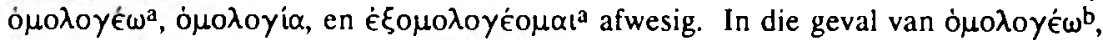

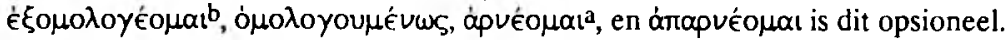

Toeligting e: Die vermelding van eie trou as inhoud van kommunikasie is net en nood-

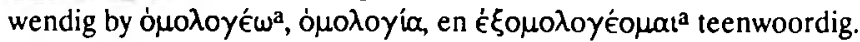

Toeligting f: Waarheid as inhoud van kommunikasie is net - uit die oogpunt van die

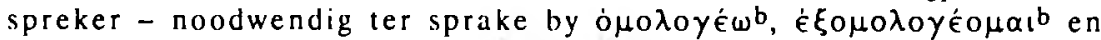

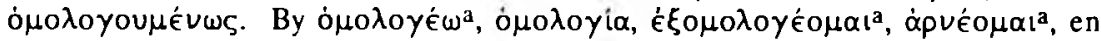
árapvéouat is dit opsioneel.

Toeligting \&: Erkenning of ontkenning as inhoud van kommunikasie is by $\mu_{0} \lambda \lambda_{0} \epsilon^{\mathrm{t}} \omega^{\mathrm{a}}$,

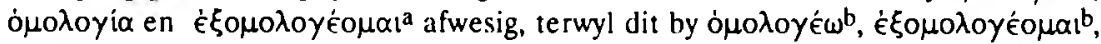

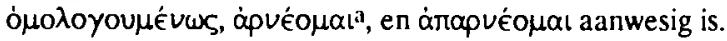

\section{$3.4 \quad$ Gevolgtrekking}

Binne Domein 33 is slegs Betekenis 33.274 en Betekenisse 33.275-33.277 (dit wil sê Subdomeine $U$ en $V$ ) ter sake. Die Griekse woorde wat vir hierdie betekenisse

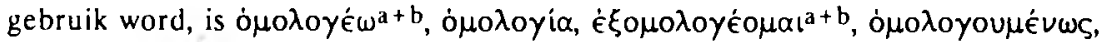

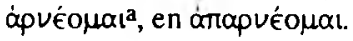

Subdomeine $U$ en $V$ vorm 'n onderdeel van Subdomeine $R-V$, wat almal geïmpliseerde waarheid en die relasie van die spreker tot daardie waarheid as belangrike faktor het. Die kontrastering van Subdomeine R-V laat blyk dat by die betekenisse van Subdomeine $U$ en $V$ die volgende komponente noodwendig afwesig is: oorreding as ongmerk met die kommunikasie; bedrog as oogmerk met die kommunikasie; betuiging van 'n persoon/saak as oogmerk met kommunikasie; negatiewe betuiging as oogmerk met die kommunikasie. Die volgende komponente is weer uniek aan Subdomeine $U$ en V, dit wil sê afwesig by $\mathrm{R}-\mathrm{T}$ : vermelding van eie trou as oogmerk met die kommunikasie; vermelding van eie trou as inhoud van die kommunikasie.

Ten opsigte van die Griekse woorde wat vir die betekenisse in Subdomeine $\mathrm{U}$ en $\mathrm{V}$

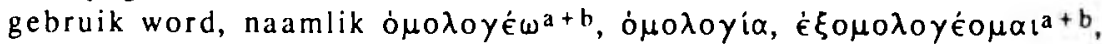
ó betekenisse belangrike gegewens, soos in toeligtingspunte (a)-(g) aangetoon, aan die lig gebring. 


\section{SAMEVATTENDE GEVOIGTREKKING}

Die voorwerpsinne en/of direkte rede by die volgende werkwoorde word aangemerk as van sekondêre belang by die bestudering van die bely/belydenis-motief in die Nuwe

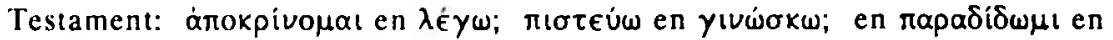
$\pi \alpha \rho \alpha \lambda \alpha \mu \beta \alpha \dot{\alpha} \omega \omega$. Die volgende selfstandige naamwoorde val in dieselfde kategorie:

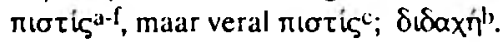

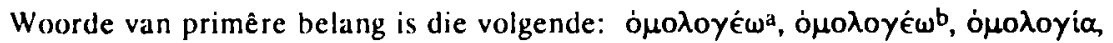

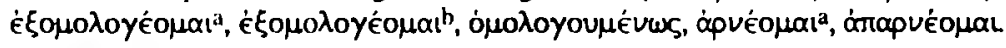

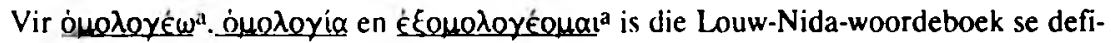
nisie die volgende: to express openly one's allegiance to a proposition or person (Louw \& Nida 1988,I:419). Op grond van die kontrastering kan die volgende presisering gegee word: die feit dat die handeling openlik is, sluit nie uit dat dit privaat, dit wil sê nie in die openbaar nie, kan wees; die Evangelic of leerstellings as inhoud van die kommunikasie is afwesig; die vermelding van eie trou as oogmerk met en as inhoud van die kommunikasie, is uniek alan hierdie woorde; waarheid as inhoud van die kommunikasie is opsioneel; erkemning/ontkenning as inhoud van die kommunikasie is afwesig; oorreding as oogmerk met dic kommunikasie is afwesig; bedrog as oogmerk met die kommunikasie is afwesig; betuiging van 'n persoon of saak is afwesig; hoop as inhoud van die kommunikasic is opsioneel; eerstehandse kennis as inhoud van die kommunikasie is opsioneel.

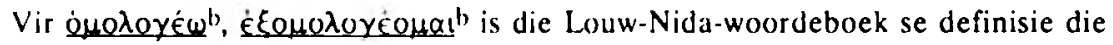
volgende: to acknowledge a fact publicly, often in reference to previous bad behaviour (Louw \& Nida 1988,I:420). Op grond van die kontrastering kan die volgende presisering gegee word: die aard van die kommunikasie is noodwendig openbaar en nie privaat nie; die Evangelie of leerstellings as inhoud van die kommunikasie is opsioneel; waarheid as inhoud van die kommunikasie is, in elk geval uit die oogpunt van die spreker, noodwendig teenwoordig; erkenning/ontkenning as inhoud van die kommunikasie is aanwesig; oorreding as oogmerk met die kommunikasie is afwesig; bedrog as oogmerk met die kommunikasie is afwesig; betuiging van 'n persoon of saak is afwesig; hoop as inhoud van die kommunikasie is opsioneel; eerstehandse kennis as inhoud van die kommunikasie is opsioneel.

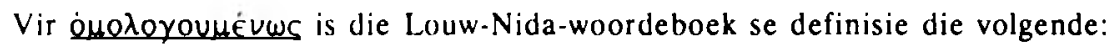
pertaining to what must or should be admitted or acknowledged publicly (Louw \& Nida 1988,I:420). Op grond van die kontrastering geld die volgende presisering: die aard van die kommunikasie is noodwendig openbaar en nie privaat nie; die Evangelie of leerstellings as inhoud van die kommunikasie is opsioneel; waarheid as inhoud van die 
kommunikasie is, in elk geval uit die oogpunt van die spreker, noodwendig teenwoordig; erkenning/ontkenning as inhoud van die kommunikasie is aanwesig; oorreding as oogmerk met die kommunikasie is afwesig; bedrog as oogmerk met die kommunikasie is afwesig; betuiging van 'n persoon of saak is afwesig; hoop as inhoud van die kommunikasie is opsioneel; eerstehandse kennis as inhoud van die kommunikasie is opsioneel.

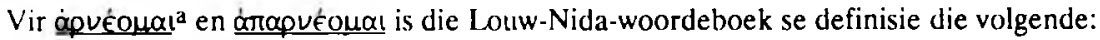
to say that one does not know about or is in any way related to a person or event (Louw \& Nida 1988.I:420). Op grond van die kontrastering kan die volgende presisering gegee word: die feit dat die handeling openlik is, sluit nie uit dat dit privaat, dit wil sề nie in die openbaar nie, kan wees; die Evangelie of leerstellings as inhoud van die kommunikasie is opsioneel; waarheid as inhoud van die kommunikasie is opsioneel; erkenning/ontkenning as inhoud van die kommunikasie is aanwesig; oorreding as oogmerk met die kommunikasie is afwesig; bedrog as oogmerk met die kommunikasie is afwesig; betuiging van ' $n$ persoon of saak is afwesig; hoop as inhoud van die kommunikasie is opsioneel; eerstehandse kennis as inhoud van die kommunikasie is opsioneel.

\section{AANGEHAALDE BRONNE}

ALAND, K.M., BLACK, C.M., MARTINI, B.M., METZGER, B.M. \& WIKGREN A. cds, 1983. The Greek New Testament (Third Corrected Edition). Stuttgart : United Bible Socictics.

BOTHA, J. 1989a. Die Louw-Nida-Woordebock - 'n Kragtige nuwe hulpmiddel vir die eksegeet, prediker en Bybelvertaler. In die Skrifig (23) 1989:1-23.

BOTHA, J. 1989b. 'n Prakticse riglyn vir die gebruik van die Louw-Nida-Woordeboek, getillustreer aan die hand van die betckenis van kaipós in (jalasiërs 6 : 9-10. In die Skriflig (23) 1989:24-39.

DELLING, G. 1967. sv $\lambda \alpha \mu \beta \alpha \nu \omega$, ktl. TDNT, IV : 5-15.

GLOER, W.H. 1984. Homologies and hymns in the New Testament : form, content and criteria for identification. Perspectives on Religious Studies, 11:115-132.

HENDRIKSEN, W. 1981. Romans. Volume 2: Chapters 9.16. Edinburgh : Banner of Truth Trust.

LOUW, J.P. \& NIDA, E.A. 1988. Greck-English Lexicon of the New Testament based on semantic domains. Volumes I \& II. New York: United Bible Societics.

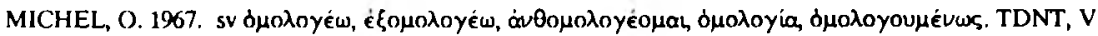
: 199.220.

NEUFELD, V.H. 1963. The carliest Christian Confessions. Grand Rapids : Eerdmans. (New Testament Tools and Siudies 5.)

SCHAFF. P. 1877. The crecds of the Greck and Latin churches. London : Hodder \& Stoughton. 